GRASAS Y ACEITES 65 (3)

July-September 2014, e033

ISSN-L: 0017-3495

doi: http://dx.doi.org/10.3989/gya.122713

\title{
Kinetic parameter determination of roasted and unroasted argan oil oxidation under Rancimat test conditions
}

\author{
I. Zaanoun ${ }^{\mathrm{a}, \mathrm{b}}$, S. Gharby ${ }^{\mathrm{c}}$, I.Bakass $^{\mathrm{a}}$, E. Ait addi ${ }^{\mathrm{a}, \varpi}$ and I. Ait ichou ${ }^{\mathrm{d}}$ \\ ${ }^{\text {a }}$ Equipe de recherche de Biotechnologie, Energie et Environnement, École Supérieure de \\ Technologie, Université Ibn Zohr, B.P. 33/S, Agadir, Morocco \\ ${ }^{\mathrm{b}}$ Ecole ploytechnique d'Agadir, Universiapolis, Bab Al Madina, quartier Tilila, B.P. 8143, Agadir, Morocco \\ ${ }^{c}$ Laboratoire de Chimie des Plantes et Synthèse Organique, Département de Chimie, Faculté \\ des Sciences, Université MohammedV-Agdal, BP1014, Rabat, Morocco \\ ${ }^{\mathrm{d}}$ Laboratoire des Systèmes Aquatiques: Milieux Marin et Continental, Faculté des Sciences, \\ Université Ibn Zohr, B.P. 8106, Agadir, Morocco \\ Corresponding author: e.aitaddi@uiz.ac.ma
}

Submitted: 12 December 2013; Accepted: 26 March 2014

SUMMARY: The present study investigated the Kinetic parameter determination of edible argan oil (coldpressed from roasted argan kernels) and cosmetic argan oil (cold-pressed from unroasted argan kernels) under the Rancimat test conditions. The physicochemical parameters of edible and cosmetic argan oil immediately after preparation and after accelerated oxidation test Rancimat at different temperatures $90{ }^{\circ} \mathrm{C}, 100{ }^{\circ} \mathrm{C}, 110^{\circ} \mathrm{C}$, $120^{\circ} \mathrm{C}, 130^{\circ} \mathrm{C}$ and $140{ }^{\circ} \mathrm{C}$ were determined and compared. The natural logarithms of the kinetic rate constant (kvalue) varied linearly with respect to temperature. An increasing rate of oxidation could be observed as temperature increased. On the basis of the Arrhenius equation and the activated complex theory, frequency factors $\mathrm{A}$, activation energies Ea, Q10 numbers, activation enthalpies $\Delta \mathrm{H}$, and activation entropies $\Delta \mathrm{S}$ for oxidative stability of the vegetable oils were calculated. The accelerated oxidation and Kinetic parameters have shown that edible argan oil can be stored much better than cosmetic oil.

\section{KEYWORDS: Argan oil; Kinetic parameters; Oxidative stability; Rancimat; Roasting}

RESUMEN: Determinación de parámetros cinéticos de la oxidación mediante Rancimat de aceites de argán tostado y sin tostar. En presente estudio se determinaron los parámetros cinéticosde aceites de argán comestible (prensado en frío a partir de granos tostados de argán) y cosmético (prensado en frío a partir de granos de argán sin tostar) bajo las condiciones del método Rancimat. Se determinó y comparó los parámetros físico-químicos de aceites de argán comestible y cosmético inmediatamente después de la preparación y después de la oxidación acelerada mediante Rancimat a temperaturas de $90^{\circ} \mathrm{C}, 100^{\circ} \mathrm{C}, 110^{\circ} \mathrm{C}, 120^{\circ} \mathrm{C}, 130^{\circ} \mathrm{C}$ y $140{ }^{\circ} \mathrm{C}$ Los logaritmos naturales de la constante de velocidad cinética (valor k) variaron linealmente con respecto a la temperatura. Se pudo observar un valor creciente de la oxidación conel aumento de la temperatura. Se calculó para la estabilidad oxidativa de los aceites vegetalesy sobre la base de la ecuación de Arrhenius y la teoría del complejo activado, la frecuencia de los factores $\mathrm{A}$, energías de activación $\mathrm{Ea}$, los valores de $\mathrm{Q} 10$, lasentalpías de activación $\Delta \mathrm{H}$, y las entropías de activación $\Delta \mathrm{S}$. La oxidación acelerada y los parámetros cinéticos han demostrado que el aceite de argán comestible se puede almacenar mucho mejor que el aceite cosmético.

PALABRAS CLAVE: Aceite de argán; Estabilidad oxidativa; Parámetros cinéticos; Rancimat; Tostado

Citation/Cómo citar este artículo: Zaanoun I, Gharby S, Bakass I, Ait addi E, Ait ichou I. 2014. Kinetic parameter determination of roasted and unroasted argan oil oxidation under Rancimat test conditions. Grasas Aceites 65 (3): e033. doi: http://dx.doi.org/10.3989/gya.122713.

Copyright: (C) 2014 CSIC. This is an open-access article distributed under the terms of the Creative Commons Attribution-Non Commercial (by-nc) Spain 3.0 Licence. 


\section{INTRODUCTION}

Argan oil, a typical Moroccan product, is prepared from the fruits of argan trees (Argania spinosa L. Skeels). It is extracted by pressing the argan kernels through a multistep process (Charrouf et al., 2002; Matthaus et al., 2010). Edible argan oil is obtained when the kernels are slightly roasted prior to grinding (Gharby et al., 2011). Unroasted kernels are used to prepare a cosmetic oil (Faez et al., 2013; Guillaume and Charrouf, 2011).

For years, argan oil has been prepared exclusively by Berber women through a traditional multistep process (Charrouf et al., 2002).

Unfortunately, this method is time consuming for producing oil batches with different organoleptic properties due to the non-reproducible roasting (Charrouf et al., 2006) and chemical composition of oil batches (Matthaus et al., 2010; Gharby et al., 2011). In addition, bacteriological concerns are frequently raised (Gharby et al., 2011).

Recently,in the women's cooperatives,argan oil has been extracted using mechanical presses producing a high quality of oil on a large scale (Charrouf et al., 2002). At present, the production of high quality argan oil is particularly important since it has been reported to promote several benefits for human health (Charrouf and Guillaume 2008). However, as a consequence of its high degree of unsaturation, argan oil is very susceptible to oxidation (Gharby et al., 2011).

Lipid oxidation in vegetable oils is one of the most important reactions that can cause the deterioration of their quality. The oxidation process of edible oil results in the development of undesirable flavors which affect the sensory quality and considerably reduce the pharmaceutical and food use of these oils (Jacobsen and Nielsen 2008; Matthaus et al., 2010). Therefore, the monitoring of the oxidative stability of argan oil is of great importance for producers and manufacturers in order to control and optimize the production process and to predict the shelf-life of the final oil (Gharby et al., 2011).

A number of accelerated methods have been developed to test the resistance of edible fats and oils to oxidation. All these accelerated methods involve the use of elevated temperatures because it is known that the rate of the reaction is exponentially related to temperature (Reynhout, 1991). Among them, the Rancimat test, due to its ease of use and reproducibility, has become frequently used and reviewed (Hasenhuettl and Wan 1992; Matthäus 1996; Mendez et al., 1996; Anwar et al., 2003; Kowalski et al., 2004; Gonzaga et al., 2007; Farhoosh 2007; Gharby et al., 2012).

This test allows for the determination of the induction period (IP) or oil/oxidative stability index (ISO-6886), which is the time before rapid deterioration of the oil occurs. The oxidative stability index can be determined at various temperatures and, therefore, the relative oxidative stability of edible fats and oils can be evaluated in a range of temperatures. In addition, previous studies have demonstrated the correlation between the stability data obtained by the Rancimat test and those determined by other sensory and/or analytical methods (Anwar et al., 2003; Adhvaryu et al., 2000; Kowalski et al., 2004; Gordon and Mursi, 1994).

A number of kinetic parameters can be determined under the Rancimat test conditions. Kinetic data can be used to characterize the differences or similarities in the oils. These data are very useful for predicting the oxidative stability of vegetable oils under various heat processing, storage, and distribution conditions (Tan et al., 2001). Also, a whole series of experiments and calculations of kinetic data for each argan oil under the Rancimat test conditions can be performed relatively quickly.

The aim of the present study was to determine the relative oxidative stabilities of argan oil obtained from roasted and unroasted kernels and the kinetic parameters of their oxidation under the Rancimat test conditions.

\section{MATERIALS AND METHODS}

\subsection{Materials}

Argan fruits $(600 \mathrm{Kg})$ were collected in Ait Baha, (Province of Chtouka Ait baha, Morocco). The fruit was dried and peeled using the argan-cooperative traditional technique (Charrouf and Guillaume, 2008). Argan nuts were manually opened using the traditional method and a fraction of the kernels $\left(150 \mathrm{Kg}\right.$ ) was roasted at $110^{\circ} \mathrm{C}$ for $25 \mathrm{~min}$ (Harhar et al., 2011, El Manfalouti et al., 2013). The argan oil was produced by mechanical pressing of kernels according to the method described by Hilali et al. (2005). Therefore, two types of argan oil were analyzed: (1) argan oil from unroasted kernels (UAO); (2) argan oil from roasted kernels (RAO).

All chemicals and solvents used were of analytical reagent grade (Merck, Darmstadt, Germany).

\subsection{Chemical analysis}

The determination of physicochemical parameters (acidity, peroxide value, UV-light absorption (K232 and K270), was carried out according to the analytical methods described by Regulation EEC/ 2568/91 and EEC/ 1429/92 of the European Union Commission $(1991,1992)$. Acidity, given as percentage of oleic acid, was determined by titration of a solution of oil dissolved in $\mathrm{EtOH} / \mathrm{Et}_{2} \mathrm{O}$ (1:1) with $0.1 \mathrm{M} \mathrm{KOH}$ in EtOH. To determine the peroxide value, expressed as milli-equivalents of active oxygen per kilogram of oil (meq $\mathrm{O}_{2} \cdot \mathrm{kg}^{-1}$ ), a mixture of oil and iso-octane-acetic acid was left to react 
with a solution of KI in the dark; the free iodine was then titrated with a sodium thiosulfate solution. UV-light absorption (K270 and K232) was measured in cyclohexane using a Cary 100 Varian UV spectrophotometer as previously described (Harhar et al., 2010).

For the determination of fatty acid composition, the methyl esters were prepared by cold transmethylation in a basic medium (IOOC, 2001) and were analyzed in a gas phase chromatograph (HP 6890, Agilent) fitted with aCP-Wax52CB column $(30 \mathrm{~m}$ 0.25 mmi.d.) using helium (flow rate $1 \mathrm{~mL} \cdot \mathrm{min}^{-1}$ ) as the carrier gas. The initial oven temperature was set at $170{ }^{\circ} \mathrm{C}$; the injector temperature at $200{ }^{\circ} \mathrm{C}$; and the detector temperature at $230{ }^{\circ} \mathrm{C}$. The injected quantity was $1 \mu \mathrm{L}$ for each analysis.

The tocopherol content was determined on the basis of the AOCS Official method Ce8-89 (AmericanOil Chemists'Society, 1993). Tocopherols were analyzed by HPLC using Shimadzu instruments equipped with a C18-Varian column $(25 \mathrm{~cm} \times 4 \mathrm{~mm})$. Detection was performed using a fluorescence detector (excitation wavelength $290 \mathrm{~nm}$, detection wavelength $330 \mathrm{~nm}$ ). The eluent used was a 99:1 isooctane/isopropanol $(\mathrm{V} / \mathrm{V})$ mixture at a flow rate of $1.2 \mathrm{~mL} \cdot \mathrm{min}^{-1}$. Phosphorus content was determined using the NF T60-227 recommendation (Paquot and Hautfenne, 1987). Beta-Carotene content was determined using a PFX-995 lovibond tintometer (cell length $10 \mathrm{~mm}$ ).

\subsection{Rancimat test}

A Metrohm Rancimat model 743 (Herisau, Switzerland) was used. In order to establish airsaturated conditions in the oil samples, the tests were carried out with $3 \mathrm{~g}$ of the oil samples at temperatures of $90{ }^{\circ} \mathrm{C}, 100{ }^{\circ} \mathrm{C}, 110^{\circ} \mathrm{C}, 120^{\circ} \mathrm{C}, 130^{\circ} \mathrm{C}$ and $140^{\circ} \mathrm{C}$ at an airflow rate of $20 \mathrm{~L} / \mathrm{h}$. Samples for all determinations were randomized on their position in the heating block.

The glassware was rigorously cleaned between runs to avoid any contamination that would catalyze peroxidation. Measuring vessels, electrodes, and connecting tubes were cleaned several times with alcohol and distilled water, and were blown out with nitrogen before the experiment (Farhoosh et al., 2008).

\subsection{Statistical analysis}

All Rancimat experiments and measurements were carried out in triplicate, and the data were subjected to analysis of variance (ANOVA). ANOVA and regression analyses were performed according to the SPSS software. Significant differences between means were determined by Duncan's multiple range Tests; $p$ values less than 0.05 were considered statistically significant.

\section{RESULTS AND DISCUSSION}

The initial compositions of the argan oils studied are summarized in Table 1. All samples fulfil the requirements of Moroccan Regulations for extra virgin argan oil (EVAO): acidity, $\mathrm{PV}$ and K270 (SNIMA 2003). The amount of free FAs is an indicator of the quality and is traditionally used as an indicator for the classification of the different commercial types from EVAO (Gharby et al., 2012). It can be seen that at the beginning of this study, all EVOO varieties showed an acidity index of $0.3 \%$, which is much lower than the regulated $0.8 \%$ as the maximum for any EVOO. Concerning PV, this index is considered to be an indicator of primary oxidation (Gharby et al., 2011). The two argan oils considered here showed low PV values, with the cosmetic argan oil yielding the highest value at 0.9 meq $\mathrm{O}_{2} \cdot \mathrm{kg}^{-1}$. In any case, none of the analyzed oils surpassed $15 \mathrm{meq} \mathrm{O}_{2} \cdot \mathrm{kg}^{-1}$ oil, which is the limit established for EVAO (SNIMA 2003). Another quality index specified in Moroccan Regulations is K270 (Rahmani, 2005). An increase indicates that oil oxidation has begun, which could be due to some factors affecting storage conditions or to an inadequate EVAO processing (Cayuela et al., 2008). In this study, K270 coefficients were less than 0.2, compared to a maximum established by Moroccan Regulations for EVAO of 0.35 .

We also found that there was no statistically significant difference among the percentages of saturated fatty acids SFA and unsaturated fatty acids (MUFA+PUFA) of the roasted and unroasted argan oil.

The initial content of tocopherol, in the oil prepared from roasted seeds was $791.2 \mathrm{ppm}$; it differs significantly from the corresponding values in oils from unroasted seeds of $667.04 \mathrm{ppm}$. The beta-carotene

TABLE 1. Initial quality characteristics and fatty acid composition of the argan oils

\begin{tabular}{lcc}
\hline & RAO & UAO \\
\hline Acid Value $(\%)$ & $0.18 \pm 0.01$ & $0.38 \pm 0.01$ \\
Peroxide value $\left(\mathrm{meq} \mathrm{O}_{2} \cdot \mathrm{kg}^{-1}\right)$ & $0.54 \pm 0.06$ & $0.98 \pm 0.02$ \\
K232 & $1.38 \pm 0.026$ & $1.25 \pm 0.01$ \\
K270 & $0.25 \pm 0.023$ & $0.22 \pm 0.01$ \\
$\beta$-carotene (ppm) & $19,96 \pm 0.13$ & $8.62 \pm 0.14$ \\
Phosphorus (ppm) & $42.81 \pm 0.14$ & $2.06 \pm 0.03$ \\
Phospholipid $\left(\mathrm{mg} \cdot 100 \mathrm{mg}^{-1}\right)$ & 0.3 & 0.006 \\
SFA (mg $\left.\cdot 100 \mathrm{mg}^{-1}\right)$ & $19 \pm 0.7$ & $19.45 \pm 0.17$ \\
MUFA (mg $\left.\cdot 100 \mathrm{mg}^{-1}\right)$ & $46.35 \pm 0.72$ & $46.25 \pm 0.37$ \\
PUFA (mg $\left.100 \mathrm{mg}^{-1}\right)$ & $34.65 \pm 0.72$ & $34.30 \pm 0.37$ \\
Tocopherols $(\mathrm{ppm})$ & 791.91 & 667.04 \\
\hline
\end{tabular}

SFA: Saturated fatty acid; MUFA: Mono unsaturated fatty acid; PUFA: Polyunsaturated fatty acid. 
TABLE 2. The reaction rate constants $(\mathrm{k})$ of the argan oils at different temperatures

\begin{tabular}{lcccccc}
\hline \multicolumn{7}{c}{$\mathbf{K} \pm \mathbf{S D}\left(\times \mathbf{1 0}^{\mathbf{3}}\right)\left[\mathbf{h}^{-1}\right]$} \\
\hline Oil & $\mathbf{9 0}$ & $\mathbf{1 0 0}$ & $\mathbf{1 1 0}$ & $\mathbf{1 2 0}$ & $\mathbf{1 3 0}$ & $\mathbf{1 4 0}$ \\
\hline Roasted Argan Oil & $7.09 \pm 0.15$ & $16.69 \pm 0.69$ & $32.26 \pm 0.25$ & $63.13 \pm 0.89$ & $131.58 \pm 0.98$ & $294.12 \pm 0.85$ \\
Unrosted Argan Oil & $16.89 \pm 0.72$ & $36.66 \pm 0.34$ & $83.33 \pm 0.48$ & $158.73 \pm 0.57$ & $335.57 \pm 0.84$ & $781.25 \pm 0.75$ \\
\hline
\end{tabular}

$\mathrm{SD}$, Standard deviation.

and the phosphorus/phospholipid contents were significantly lower in the beauty oil than in the edible oil. Beta-Carotene is a very lipophilic molecule that is known to present antioxidant properties in synergy with $\alpha$-tocopherol (Palozza and Krinsky, 1992). However, no precise results can be given concerning the influence ofbeta-carotene onthe oxidative stability of edible argan (Gharby et al., 2011). The phospholipid content of the edible argan oil was found to be ten-times higher than that of the beauty oil ( $0.3 \mathrm{vs} 0.006 \mathrm{mg} \cdot 100 \mathrm{mg}^{-1}$, respectively). Interestingly, the phosphorus/phospholipid content of the beauty oil was found to be as low as that of artisanally-prepared argan oil (Gharby et al., 2011), the extraction of which is completed by a waterassisted stage. Such a hypothesis is fully consistent with the known fact that the simultaneous presence of phospholipids, $\beta$-carotene and tocopherols, which are abundant in argan oil, act synergistically as antioxidants in oils (Weng and Gordon, 1993; Lee et al., 2004; Steel et al., 2005). The k values for lipid oxidation of each argan oil at each temperature are presented in Table 2. By studying the rates of lipid oxidation as a function of temperature, an increasing rate of oxidation can be observed as temperature increases (Gharby et al., 2011). As shown in Fig. 1, the semi-logarithmic relationship between $\mathrm{k}$ and $\mathrm{T}$

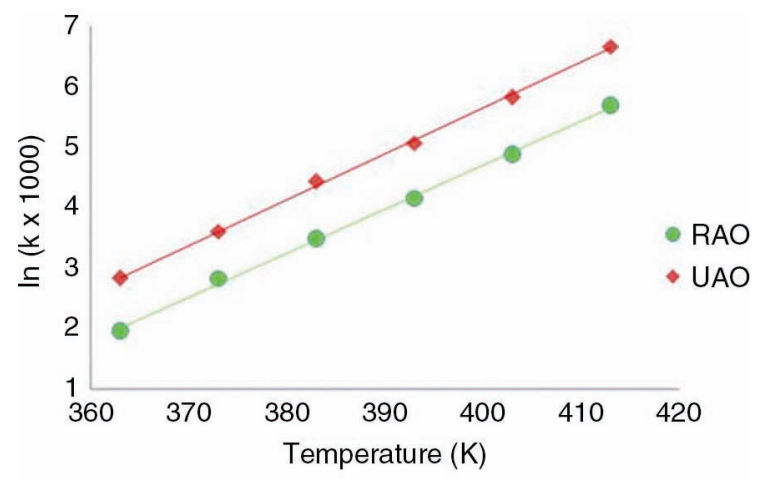

\begin{tabular}{ccccc}
\multicolumn{5}{c}{$\mathbf{L n}(\mathbf{k})=\mathbf{a}(\mathbf{T})+\mathbf{b}$} \\
\hline & $\mathbf{a}$ & $\mathbf{b}$ & $\mathbf{R}^{\mathbf{2}}$ & $\mathbf{T}_{\mathbf{c o e f}} \times \mathbf{1 0}^{-\mathbf{2}}\left(\mathbf{k}^{\mathbf{- 1}} \mathbf{)}\right.$ \\
\hline - RAO & 0.072 & -24.43 & 0.998 & 7.2 \\
- UAO & 0.075 & -24.59 & 0.998 & 7.5
\end{tabular}

FIGURE 1. Semi-logarithmic relationship between $\mathrm{k}$ and $\mathrm{T}$ values for lipid oxidation of the argan oils. values in all argan oils showed a linear dependency with good correlation of determination $\left(\mathrm{R}^{2}>0.99\right)$. The lipid oxidation at low and high temperatures may go through different steps or reaction pathways, depending on the reactivity of metal ions and antioxidants at different temperatures (Tan et al., 2001). Moreover, the oil temperature affects the degree of oxygen solubility in vegetable oils which decreases by almost $25 \%$ for each $10{ }^{\circ} \mathrm{C}$ rise in temperature (Robertson, 2000). The $\mathrm{T}$ coeff values calculated from the linear functions in Fig. 1 for the argan oils ranged from $7.2 \times 10^{-2}$ to $7.5 \times 10^{-2} \mathrm{~K}^{-1}$. These values could be interpreted as quantities representative of the argan oils studied. Our values are in accordance with Farhoosh and Moosavi (2007), who reported such values between $6.5 \times 10^{-2}$

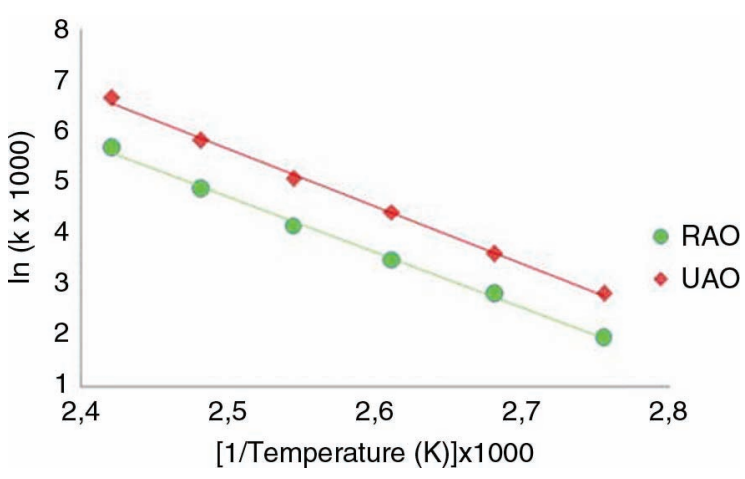

FIGURE 2. Semi-logarithmic relationship between $\mathrm{k}$ and $(1 / T)$ values for lipid oxidation of the argan oils.

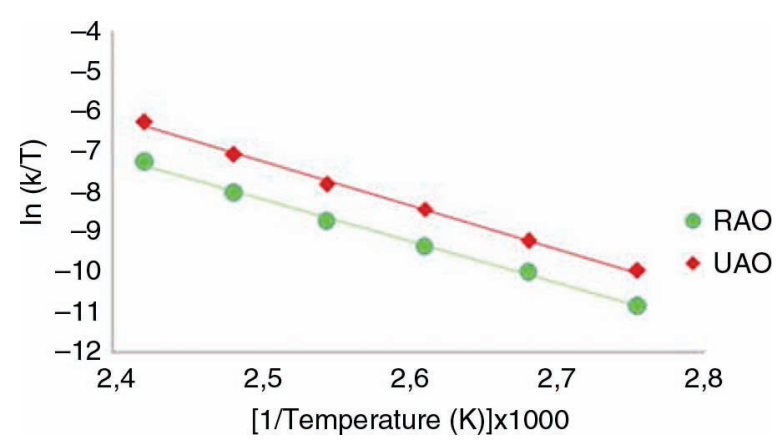

Figure 3. Semi-logarithmic relationship between $(\mathrm{k} / \mathrm{T})$ and $(1 / \mathrm{T})$ values for lipid oxidation of the argan oils. 
TABLE 3. Regression parameters for Arrhenius relationships between the reaction rate constant and the temperature for the argan oils

\begin{tabular}{lcccccc}
\hline & \multicolumn{2}{c}{$\ln (\mathbf{k})=\ln (\mathbf{A})-(\mathbf{E a} / \mathbf{R})^{*}(\mathbf{1} / \mathbf{T})$} & & & \\
\cline { 2 - 5 } & $\mathbf{a}$ & $\mathbf{b}$ & $\mathbf{R}^{\mathbf{2}}$ & $\mathbf{E a}$ & $\mathbf{A}$ & $\mathbf{Q}_{\mathbf{1 0}}$ \\
\hline$\cdot$ RAO & -10.91 & 32 & 0.997 & 90.71 & $7.8910^{13}$ & 2.11 \\
$\bullet$ UAO & -11.32 & 33.97 & 0.997 & 94.12 & $5.6610^{14}$ & 2.16 \\
\hline
\end{tabular}

TABLE 4. Activation enthalpies $\Delta \mathrm{H}$ and entropies $\Delta \mathrm{S}$ for lipid oxidation of the argan oils

\begin{tabular}{|c|c|c|c|c|c|}
\hline & \multicolumn{3}{|c|}{$\ln (k / T)=\ln \left(k_{B} / h\right)+(\Delta S / R)-(\Delta H / R) \times(1 / T)$} & \multirow[b]{2}{*}{$\Delta \mathbf{H}$} & \multirow[b]{2}{*}{$\Delta \mathbf{S}$} \\
\hline & $\mathbf{a}$ & b & $\mathbf{R}^{2}$ & & \\
\hline$\cdot$ RAO & -10.52 & 18.13 & 0.996 & 87.47 & -46.81 \\
\hline • UAO & -10.93 & 20.11 & 0.997 & 90.87 & -30.35 \\
\hline
\end{tabular}

to $7.4 \times 10^{-2} \mathrm{~K}^{-1}$ (mean value: $7.17 \times 10^{-2} \mathrm{~K}^{-1}$ ) in the case of other oils (canola, soybean, sunflower, olive and corn oils) (Farhoosh et al., 2008).

Table 3 provides the regression parameters for Arrhenius relationships between the reaction rate constant and the temperature for the argan oils studied. Using these regression parameters, the frequency factors, activation energies, and $\mathrm{Q}_{10}$ numbers for the formation reaction of the secondary oxidation products under the Rancimat test conditions (volatile acids, mostly formic acids, with lesser amounts of acetic, propionic, and other acids) were calculated (de Man et al., 1987). These quantities for the lipid oxidation of the argan oils under the Rancimat test conditions differed significantly. This implies that the production of volatile acids under these conditions was dependent on the oil source, so it affected the assessment of the relative stability of the argan oils (Mendez et al., 1996).

The results obtained showed that a high content of $\beta$-Carotene, Phospholipid and Phosphorus would improve resistance to lipid oxidation (increase the Ea value). These would result in delaying the onset of the initial oxidation process where bond scission takes place to form primary oxidation products. The B Carotene, Phospholipid and Phosphorus contents of the argan oils (Table 1) explain the observed trends in various activation energies (Table 3 ) to a certain extent. However, it was observed that several other factors affecting the oxidative stability, e.g. the tocopherol content influenced the susceptibility to oxidative degradation to varying extents. The frequency factors with a trend similar to that of the Ea values for the argan oils studied increased from 7.89 $10^{13}$ for RAO to $5.6610^{14}$ for UAO.

The magnitude of the temperature effect on the oxidation rate of the argan oils was evidenced by the $\mathrm{Q}_{10}$ numbers. In general, a higher $\mathrm{Q}_{10}$ number implies that a smaller temperature change is needed to induce a certain change in the rate of lipid oxidation. As can be seen in Table 3, the $\mathrm{Q}_{10}$ number increased from 2.11 for RAO to 2.16 for UAO.

The $\Delta \mathrm{H}$ and $\Delta \mathrm{S}$ values estimated based on the activated complex theory and the corresponding regression parameters are summarized in Table 4. The high correlation of determination $\left(R^{2}>0.99\right)$ indicated an adequate fit and characterization of the temperature dependence of lipid oxidation using the activated complex theory.

The $\Delta \mathrm{H}$ and $\Delta \mathrm{S}$ values for the argan oils studied ranged from $87.47 \mathrm{~kJ} \cdot \mathrm{mol}^{-1}$ and $-46.81 \mathrm{~J} \cdot \mathrm{mol}^{-1} \cdot \mathrm{K}^{-1}$ for roasted argan oil to $90.87 \mathrm{~kJ} \cdot \mathrm{mol}^{-1}$ and -30.35 $\mathrm{J} \cdot \mathrm{mol}^{-1} \cdot \mathrm{K}^{-1}$ for unroasted Argan oil, respectively. In their study on the determination of the oxidative stability of rapeseed, sunflower and soybean oils by the Rancimat test, Kowalski et al., calculated the amounts of $82 \mathrm{~kJ} \cdot \mathrm{mol}^{-1}$ and $-52.7 \mathrm{~J} \cdot \mathrm{mol}^{-1} \cdot \mathrm{K}^{-1}$, $84 \mathrm{~kJ} \cdot \mathrm{mol}^{-1}$ and $-42.8 \mathrm{~J} \cdot \mathrm{mol}^{-1} \cdot \mathrm{K}^{-1}$, and $74.9 \mathrm{~kJ} \cdot \mathrm{mol}^{-1}$ and $-70.2 \mathrm{~J} \cdot \mathrm{mol}^{-1} \cdot \mathrm{K}^{-1}$ for their $\Delta \mathrm{H}$ and $\Delta \mathrm{S}$ values, respectively (Kowalski et al. 2004). The negative values for $\Delta \mathrm{S}$ indicate that the activated complexes are more ordered than the molecules of the reactants, and its greater negative values indicate fewer numbers of species in the activated complex state, and hence a lower probability of the activated complex toward lipid oxidation and therefore a slower rate.

\section{CONCLUSIONS}

The experimental results allowed us to draw the following conclusions: An increasing rate of oxidation could be observed as temperature increases and, edible argan oil can be stored much better than cosmetic oil. 


\section{REFERENCES}

Adhvaryu A, Erhan SZ, Liu ZS, Pérez JM. 2000. Oxidation kinetic studies of oils derived from unmodified and genetically modified vegetables using pressurized differential scanning calorimetry and nuclear magnetic resonance spectroscopy. Thermochim Acta. 364, 87-97. http://dx.doi. org/10.1016/S0040-6031(00)00626-2.

Anwar F, Bhanger MI, Kazi TG. 2003. Relationship between Rancimat and Active Oxygen Method values at varying temperatures for several oils and fats. J Am Oil Chem Soc. 80, 151-155. http://dx.doi.org/10.1007/s11746-003-0668-2.

AOCS. 1993. Official Methods and Recommended Practices of the American Oils Chemists Society, AOCS Press, Champaign, IL USA.

Cayuela JA, Rada M, Pérez-Camino MC, Benaissa M, Abdelazziz E, Guinda, A. 2008. Characterization of artisanally and semiautomatically extracted argan oil from Morocco. Eur. J. Lipid Sc. Technol. 110, 1159-1166. http:// dx.doi.org/10.1002/ejlt.200800146.

Charrouf Z, Guillaume D, Driouich A. 2002. The argan tree, an asset for Morocco. Biofutur 220, 54-57.

Charrouf Z, El Hamchi H, Mallia S, Licitra G, Guillaume D. 2006. Influence of roasting and seed collection on argan oil odorant composition. Natural Product Communications, 1, 399-404.

Charrouf Z, Guillaume D. 2008. Argan oil: occurrence, composition and impact on human health. Eur. J. Lipid Sc. Technol. 110, 632-636. http://dx.doi.org/10.1002/ejlt.200700220.

DeMan JM, Tie F, deMan L. 1987. Formation of short chain volatile organic acids in the automated AOM method. $J$. Am. Oil Chem. Soc. 64, 993-996. http://dx.doi.org/10.1007/ BF02542435.

European Union Commission, Commision Regulation (EEC) No. 2568/91. 1991. On the characteristics of olive and olive pomace oilsand on their analytical methods. Off. J. Eur. Commun. L248, 29-32.

European Union Commission, Commision Regulation (EEC) No. 1429/92. 1992. On the amendment of (EEC) No. 2568/91. Off. J. Eur. Commun. L50, 17-20.

Faez M, Bchitou R, Bouhaouss A, Gharby S, Harhar H, Guillaume D, Charrouf Z. 2013. Can the dietary element content of virgin argan oils be used for adulteration detection. Food Chem. 136, 105-108. http://dx.doi.org/10.1016/j. foodchem.2012.07.098.

Farhoosh R, Moosavi SMR. 2007. Rancimat test for the assessment of used frying oils quality. J. Food Lipids, 14, 263271. http://dx.doi.org/10.1111/j.1745-4522.2007.00084.x.

Farhoosh R. 2007. The effect of operational parameters of the Rancimat method on the determination of the oxidative stability measures and shelf-life prediction of soybean oil. J. Am. Oil Chem Soc. 84, 205-209. http://dx.doi. org/10.1002/ejlt.200800004.

Farhoosh R, Niazmand R, Rezaei M, Sarabi M. 2008. Kinetic parameter determination of vegetable oil oxidation under Rancimat test conditions. Eur. J. Lipid Sci. Technol. 110, 587-592. http://dx.doi.org/10.1002/ejlt.200800004.

Gharby S, Harhar H, Guillaume D, Haddad A, Matthäus B, Charrouf Z. 2011. Oxidative stability of edible argan oil: a two year study. $L W T$. Food Sci. Technol. 44, 1-8.

Gharby S, Harhar H, Guillaume D, Haddad A, Charrouf Z. 2012. The origin of virgin argan oil's high oxidative stability unraveled. Nat. Prod. Commun. 7, 621-624.

Gonzaga FB, Pasquini C, Rodrigues CEC, Meirelles AJA. 2007. Comparison of near-infrared emission spectroscopy and the Rancimat method for the determination of oxidative stability. Eur. J. Lipid Sci. Technol. 109, 61-65. http:// dx.doi.org/10.1002/ejlt.200600185.

Gordon MH, Mursi EA. 1994. Comparison of oil stability based on the Metrohm Rancimat with storage at $207^{\circ} \mathrm{C}$. $J$. Am. OilChem. Soc. 71, 649-651. http://dx.doi.org/10.1007/ BF02540595.

Harhar H, Gharby S, Kartah B, El Monfalouti H, Guillaume D, Charrouf Z. 2011. Influence of argan kernel roasting-time on virgin argan oil composition and oxidative stability. Plant Foods for Human Nutrition, 66, 163-168. http://dx.doi.org/10.1007/s11130-011-0220-x.

Hasenhuettl GL, Wan PJ. 1992. Temperature effects on the determination of oxidative stability with the Metrohm Ranci-mat. J. Am. Oil Chem. Soc. 69, 525-527. http:// dx.doi.org/10.1007/BF02636102.

Hilali M, Charrouf Z, El Aziz Soulhi A, Hachimi L, Guillaume D. 2005. Influence of origin and extraction method on argan oil physico-chemical characteristics and composition. J. Agric. Food Chem. 53, 2081-2087. http://dx.doi. org/10.1021/jf040290t.

IOOC. 2001. Preparation of the Fatty Acid Methyl Esters from Olive Oil and Olive-Pomace Oil. International Olive Oil Council, Madrid.

ISO-6886.1989. Animal and vegetable fats and oils. Determination of oxidative stability (accelerated oxidation test).

Jacobsen C, Nielsen NS. 2008. Optimization of oxidative stability of omega-3 enriched foods. In H. Breivik (Ed.), Longchain omega-3 specialty oils (pp. 197-217). Bridgwater: The Oily Press Ltd.

Kowalski B, Ratusz K, Kowalska D, Bekas W. 2004. Determination of the oxidative stability of vegetable oils by differential scanning calorimetry and Rancimat measurements. Eur. J. Lipid Sci. Technol. 106, 165-169. http:// dx.doi.org/10.1002/ejlt.200300915.

Lee YC, Oh SW, Chang J, Kim IH. 2004. Chemical composition and oxidative stability of safflower oil prepared from safflower seed roasted with different temperatures. Food Chem. 84, 1-6. http://dx.doi.org/10.1016/S0308-8146(03)00158-4.

Matthäus BW. 1996. Determination of the oxidative stability of vegetable oils by Rancimat conductivity and chemiluminescence measurements. J. Am. Oil Chem. Soc. 73, 1039 1043. http://dx.doi.org/10.1007/BF02523413.

Matthäus B, Guillaume D, Gharby S, Haddad A, Harhar H, Charrouf Z. 2010. Effect of processing on the quality of edible argan oil. Food Chem. 120, 426-432. http://dx.doi. org/10.1016/j.foodchem.2009.10.023.

Matthaüs B. 2013. Quality parameters for cold pressed edible argan oils. Nat. Prod. Commun. 1, 37-41.

Mendez E, Sanhueza J, Speisky H, Valenzuela A. 1996. Validation of the Rancimat test for the assessment of the relative stability of fish oils. J. Am. Oil Chem. Soc. 73, 1033-1037. http://dx.doi.org/10.1007/BF02523412.

Palozza P, Krinsky NI. 1992. $\beta$-Carotene and $\alpha$-tocopherol are synergistic antioxidants. Archives of Biochemistry and Biophysics, 297, 184-187. http://dx.doi.org/10.1016/ 0003-9861(92)90658-J.

Paquot C, Hautfenne A. 1987. Standard methods for the analysis of oils, fats, and derivatives. 7 th rev. Blackwell Scientific Publications. Boston (USA).

Rahmani M. 2005. Composition chimique de l'huile d'argane vierge. Cahiers Agriculture, 14, 461-465.

Reynhout G. 1991. The effect of temperature on the induction time of a stabilizedoil. J. Am. Oil Chem. Soc. 68, 983-984. http://dx.doi.org/10.1007/BF02657549.

Robertson GL. 2000. Shelf life of packaged foods, its measurements and prediction. In: Developing New Food Products for a Changing Marketplace. Eds. A. L. Brody, J. B. Lord, Technomic Publishing, Lancaster (UK), pp. 329-353.

SNIMA-Service de normalisation industrielle-. 2003. Corps gras d'origine animale et végétale Huiles d'argane. Spécifications, Norme Marocaine NM 08.5.090. Rabat (Morocco).

Steel CJ, Dobarganes MC, Barrera-Arellano D. 2005. The influence of natural tocopherols during thermal oxidation of refined and partially hydrogenated soybean oils. Grasas Aceites, 56, 46-52. http://dx.doi.org/10.3989/gya.2005.v56. i1.133.

Tan CP, Che Man YB, Selamat JM, Yusoff SA. 2001. Application of Arrhenious kinetics to evaluate oxidative stability in vegetable oils by isothermal differential scanning calorimetry. J. Am. Oil Chem. Soc. 78, 1133-1138. http://dx.doi. org/10.1007/s11746-001-0401-1.

Weng XC, Gordon MH. 1993. Antioxidant synergy between phosphatidyl ethanolamine and $\alpha$ - tocopherylquinone. Food Chem. 48, 165-168. http://dx.doi.org/10.1016/ 0308-8146(93)90051-G. 